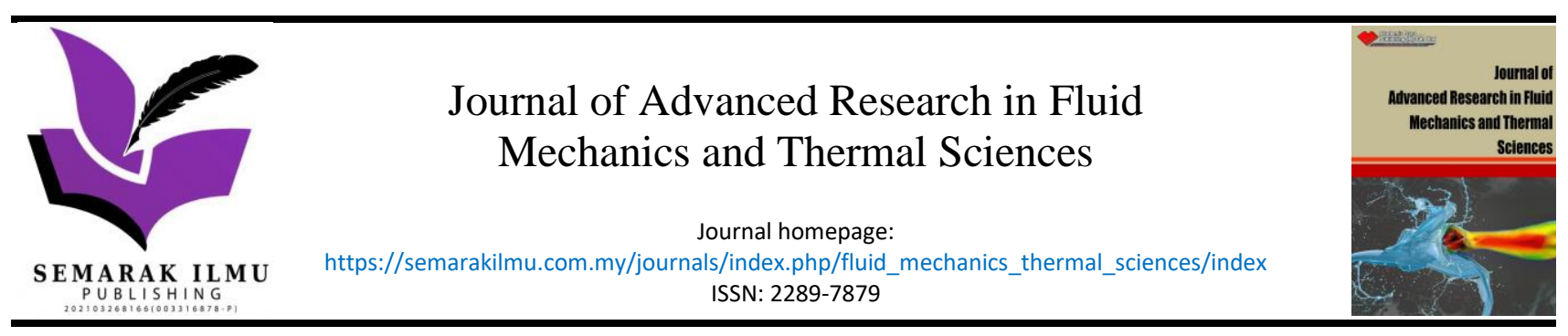

\title{
The Effect of Compression Ratio on Performance of Generator Set Fuelled with Raw Biogas
}

\author{
Sudarsono ${ }^{1}$, Anak Agung Putu Susastriawan ${ }^{1, *}$, I Gusti Badrawada ${ }^{1}$, Hary Wibowo ${ }^{1}$, Dwi Laras \\ Indrajati ${ }^{1}$
}

1 Department of Mechanical Engineering, Faculty of Industrial Technology, Institut Sains \& Teknologi AKPRIND, Yogyakarta, Indonesia

\section{ARTICLE INFO ABSTRACT}

Article history:

Received 10 June 2021

Received in revised form 13 October 2021

Accepted 25 October 2021

Available online 27 November 2021

\section{Keywords:}

Biogas; compression ratio; gen-set; performance; SI engine

\begin{abstract}
In order to utilize a raw biogas as a fuel of generator set (gen-set), it is important to figure out optimum operating parameter of the gen-set, i.e. compression ratio. The present work aims to investigate the effect of compression ratio on performance of $3 \mathrm{~kW}$ gen-set fuelled with raw biogas and to obtain optimum compression ratio for operation of the gen-set on raw biogas. The gen-set used in the present work is bi-fuel engine, i.e. fuelled with gasoline or LPG. The performance of the engine fuelled with raw biogas in terms of brake power, brake torque, brake specific fuel consumption, and thermal efficiency is evaluated at compression ratio of 7.5, 8.5, 9.5, and 10.5. The work is carried out under electrical load of 240,420, and 600 Watt. The result indicates that compression ratio affects the rotational speed, brake power, brake torque, brake specific fuel consumption, and thermal efficiency of the gen-set. Optimum compression ratio for the gen-set fuelled with raw biogas is 9.5. At the optimum compression ratio, maximum brake power, brake torque, and thermal efficiency of are $450.37 \mathrm{~W}, 1.66 \mathrm{Nm}$, and $46.93 \%$, respectively. Minimum brake specific fuel is $0.59 \mathrm{~kg} / \mathrm{kWh}$ at the optimum compression ratio.
\end{abstract}

\section{Introduction}

Many remote areas in Indonesia is still facing lack of access to electricity grid. People in those areas use either gasoline or diesel generator set to supply their electrical energy need. However, problem of fossil fuel shortage arises to them in recent years. To encounter these problems, the use of renewable energy should be adopted in electrical energy generation for rural areas. According to Indonesia Energy Projection, Indonesia has various and huge potential of renewable energy sources as can be seen in Table 1 [1]. Indonesia has renewable energy potential almost $445 \mathrm{MW}$ which are in form of about $208 \mathrm{MW}$ of solar energy, $95 \mathrm{MW}$ of hydro power, $61 \mathrm{MW}$ of wind energy, $33 \mathrm{MW}$ of bioenergy, and the rest are in form of geothermal and tidal energies. However, Indonesia growth rate of renewable energy is very low, i.e. it is only $1.98 \%$ per year within the past 10 years [2]. Since bioenergy conversion system is relatively simple and low cost, biomass has a good potential to be

\footnotetext{
* Corresponding author.

E-mail address: agung589E@akprind.ac.id
}

https://doi.org/10.37934/arfmts.89.1.185195 
converted into useful fuel, such as converted into biogas fuel via anaerobic digestion which could be applied as fuel for generator set to generate electrical energy for rural areas in Indonesia.

\begin{tabular}{|c|c|}
\hline Renewable energy form & Potential (MW) \\
\hline Solar & 32.654 \\
\hline Hydro & 75.091 \\
\hline Wind & 60.647 \\
\hline Bioenergy & 32.654 \\
\hline Geothermal & 29.544 \\
\hline Mini \& Micro Hydro & 19.385 \\
\hline Tidal & 17.989 \\
\hline Total & 443.208 \\
\hline
\end{tabular}

The use of alternative fuel for internal combustion (IC) engine has got more attention in recent years. Shortage of fossil fuel and its effect on global warming are the reasons behind the effort in searching an alternative fuel for IC engine worldwide. Various alternative fuels, for example biodiesel, ethanol, and biogas have been investigated as a fuel of IC engine, either compression ignition (CI) engine or spark ignition (SI) engine. Linn et al., 2020 [3] applied a palm oil methyl ester biodiesel as a fuel of direct injection $\mathrm{Cl}$ engine. A blend of ethanol-gasoline as fuel of SI engine has been widely reported by many researchers [4-10] and ethanol as fuel of $\mathrm{Cl}$ engine has been reported by Zulkurnai et al., 2020 [11]. Simulation work of $\mathrm{Cl}$ engine also performed in order to increase thermal efficiency of the engine and reduce NOx emission [12]. Meanwhile, the use of biogas as IC engine fuel has been presented and reported by several researchers worldwide [13-16]. Review article of biogas application in IC engine also reported by Qian et al., 2017 [17]. Reddy et al., [15] investigated the performance and exhaust gas emission of $1.4 \mathrm{kVA}$ generator set fuelled with raw biogas. The maximum power output and brake thermal efficiency were found to be $812 \mathrm{~W}$ and $19.50 \%$, accordingly. Meanwhile, carbon monoxide and hydrocarbons considerably reduced whereas nitrogen oxides concentration levels did not change significantly. Due to lower calorific value of the raw biogas than LPG, they also mentioned that power of the engine deteriorated about $32 \%$ when run on raw biogas. Faria et al., [13] performed zero differential thermodynamics equation simulation to predict the performance of an engine-generator unit fuelled with sewage biogas. The simulation showed that the model was successful in predicting how engine operating parameters can affect its performance and can be easily adapted to operate under different biogas compositions. In order to improve engine performance as well engine stability, Jatana et al., [16] proposed strategy for high efficiency and stability of biogas engine. The work obtained that combustion was fairly sensitive to the ignition strategies which in turns affected output power and continuous fuel injection was preferred that conventional intake system especially low load engine. The proposed that a combination of technologies such as lean burn, fuel injection, and dual spark plug ignition can provide highly efficient and stable operation in a biogas-fuelled small S.I. engine, especially in the low power range of 450-1000 W. The use of injection system for biogas fuelled engine was also proposed by Iremescu et al., [18]. By proper controlling of biogas injection to the combustion chamber, they found that significant improvements in fuel conversion efficiency and reductions of carbon monoxide and unburned hydrocarbons emissions.

Biogas is a gaseous fuel obtained from anaerobic digestion of various biomass feedstocks. The biogas constitutes mainly methane and carbon dioxide [19] and other gases, such as hydrogen, hydrogen sulphide, ammonia, and nitrogen. Table 2 shows a typical biogas composition [20]. However, the composition of biogas is very much depended on biomass type and properties. The 
physical, chemical and biological characteristic of biomass feedstock can affect the biogas composition and yield [21].

\begin{tabular}{ll} 
Table 2 \\
Typical composition of biogas \\
\hline Constituent & Concentration (\%) \\
\hline Methane (CH4) & $55-60$ \\
Carbon dioxide (CO2) & $35-40$ \\
Hydrogen (H2) & $2-7$ \\
Hydrogen sulphide & 2 \\
Ammonia (H2S) & $0-0.05$ \\
Nitrogen (N) & $0-2$ \\
\hline
\end{tabular}

Composition of biogas plays an important role in performance of the biogas fuelled engine. Verma et al., [14] evaluated performance and exhaust gas emission of compression ignition engine fuelled with various biogas composition. They employed exergy analysis in their investigation. They obtained that biogas dual fuel operation showed $80-90 \%$ diesel substitution at lower engine loads. At higher loads, total irreversibility of the engine was increased from $59.56 \%$ for diesel operation to $61.44 \%$, $64.18 \%$ and $64.64 \%$ for BG93, BG84 and BG75 biogas compositions respectively. Moreover, combustion irreversibility was found to be decreasing with higher $\mathrm{CO}_{2}$ concentrations in biogas. BG93 showed comparable results to that of diesel operation with $26.9 \%$ and $27.4 \%$ second-law efficiencies accordingly. Meanwhile, Sendzikiene et al., [22] studied experimentally an impact of bio-methane gas on energy and emission characteristics of a spark ignition engine. The work found that an increase in added bio-methane gas results the drop in engine power output. Two primary effects are the cylinders were refilled less effectively and reduction in the thermal efficiency of the engine. The second effect can be partially improved by accelerating the combustible ignition mixture. They were also observed that $\mathrm{CO}_{2}$ in biogas suppress combustion process which increases the content of carbon monoxide (CO) in exhaust gas, but reduces emissions of nitrous oxide (NOx). Whereas, Karagoz et al., [10] investigated an effect of $\mathrm{CO}_{2}$ ratio in biogas on the performance and vibration of spark ignition engine. The reported finding were the amplitude of the engine vibration increased as the $\mathrm{CO}_{2}$ ratio in the biogas and the engine load increased and on contrary by decreasing the $\mathrm{CO}_{2}$ ratio and increasing the engine load, cylinder pressure increased and brake specific fuel consumption decreased. They also stated that The $\mathrm{CO}_{2}$ in biogas is an important compound that affects its lower heating value (LHV), burning characteristics and exhaust emissions.

In order to obtain the best performance of the engine, selection of optimum operating parameter had to be considered during application of alternative fuel for IC engine. Compression ratio, one of many operating parameters, plays an important role on performance of the engine. Theoretically, performance of the engine increases as increasing compression ratio. Brake torque of single cylinder $\mathrm{SI}$ engine fuel with ethanol-gasoline blend was found slightly increased as compression ratio increases from 8 to 10 without knock occurrence [23]. They also stated that CO and HC emission decreased as improving compression ratio. No significant increasing of brake torque was observed when compression ratio stepped up to 13 [24]. Increasing compression ratio resulted in increasing thermal efficiency of the SI engine fuelled with biogas [25]. They mentioned that the engine reached the maximum thermal efficiency at compression ratio between 13 and 15 . The use of high compression ratio is limited by octane number of the fuel. Higher the octane number of the fuel, the higher the compression ratio can be set. Biogas has octane number of 130 [15].

In four stroke $\mathrm{SI}$ engine, compression ratio is defined as a ratio between maximum cylinder volume when the piston at bottom dead centre $(B D C)$ to the minimum cylinder volume when the 
piston at top dead centre (TDC). However, the selection of compression ratio is limited by octane number of the fuel. Typically, compression ratio of spark ignition engine lies between 7 and 10 as shown in Figure 1. By increasing compression ratio, thermal efficiency of the engine increases [26]. Combustion characteristic of the biogas is an important parameter that has to be considered related with compression ratio. Increasing compression ratio rises pressure as well as temperature of the mixture at the end of compression stroke. This affects the mixture burning during the combustion process of the internal combustion engine. The combustion mechanism of biogas is mainly based on the combustion of $\mathrm{CO}, \mathrm{CH}_{4}$ and $\mathrm{H}_{2}$ [17].

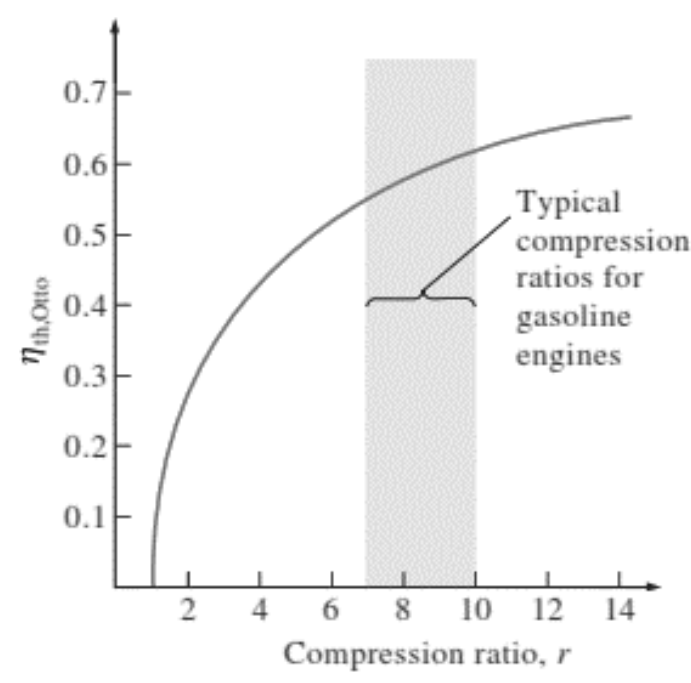

Fig. 1. An effect of compression ratio on thermal efficiency [26]

\subsection{Novelty Statement}

Although an effect of compression ratio on performance of biogas engine has been reported, but the present work is different since the investigation is conducted in spark ignition engine of generator set. The present work purposes to obtain an optimum compression ratio of single cylinder SI engine of portable generator set. Performance of the engine in terms of brake power, brake thermal, brake specific fuel consumption, and thermal efficiency are investigated at compression ratio of 7.5, 8.5, 9.5 , and 10.5 under variation of electrical load of $60,240,420,600.780$ Watt.

\section{Methodology}

\subsection{Experimental Setup}

In the present experimental work, the effect of compression ratio of 7.5, 8.5, 9.5, and 10.5 on rotational speed, brake power, brake torque, brake specific fuel consumption, and thermal efficiency of $3 \mathrm{~kW}$ generator set fuelled with a raw biogas was investigated. The raw biogas is collected from biogas digester using 3 kg LPG tank. The raw material for producing a raw biogas is a cow dung. For each compression ratio, the generator set was loaded under electric load of $60,240,420,600,780$ Watt. Figure 2 displays an experimental setup of the present work. The engine of the generator set is basically Bi-fuel engine where it can be fuelled with either gasoline or Liquid Petroleum Gas (LPG). Specification of the engine is given in Table 3. The electrical load panel is assembled from 15 electric bulbs, each of them has capacity of 60 Watt. Volumetric flow rate of the biogas is measured using a rotameter. Voltage and ampere of the generator are measured using a voltage and an ampere meter. 
Meanwhile, engine rotation is obtained by measuring engine shaft using a tachometer. In the standard condition, the engine has compression ratio of 8.5 which its maximum and clearance volume are $196 \mathrm{cc}$ and $23 \mathrm{cc}$. In order to reduce or to increase compression ratio, the cylinder head of the engine is modified. To obtain compression ratio of 7.5 , the cylinder head is trimmed in such away the clearance volume becomes $26 \mathrm{cc}$. Meanwhile to set the compression ratio of 9.5, the additional packing is attached on the internal surface of cylinder head in such away the clearance volume becomes $20.6 \mathrm{cc}$

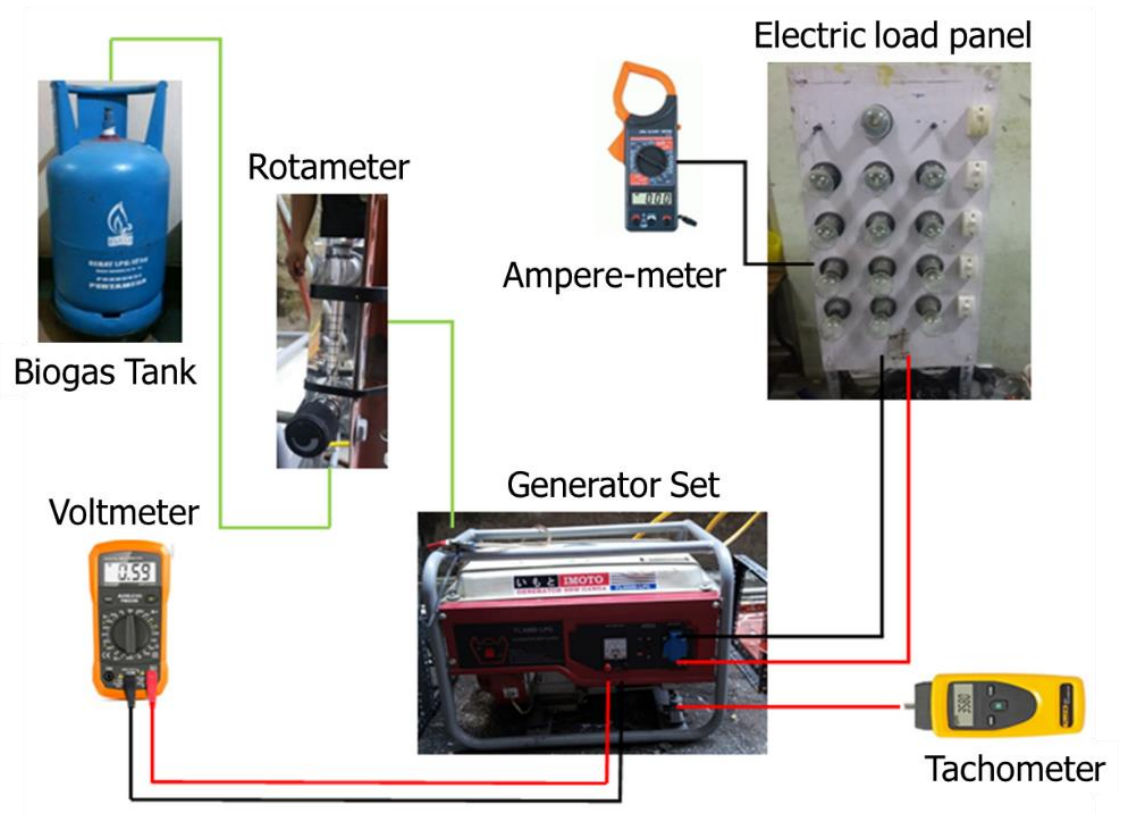

Fig. 2. Experimental setup

Table 3

Specification of the engine

\begin{tabular}{ll}
\hline Engine & Specification \\
\hline Fuel & Bi-fuel (Gasoline or LPG) \\
Type & 4-stroke, OHV, single cylinder, 196 CC \\
Power & $3 \mathrm{~kW}$ at rated speed 3000 rpm \\
Compression ratio & 8.5 (Standard) \\
Cooling system & Air cooled \\
\hline
\end{tabular}

\subsection{Calculation of Parameters}

Mass flow rate of a biogas into the engine is calculated from it volumetric flow rate read on the rotameter. Eq. (1) is used to calculate mass flow rate of a biogas

$m_{f}=\frac{Q_{f}}{\rho_{b}}$

where $Q_{f}$ is the volumetric flow rate, $\rho_{b}$ is the density of the biomass, $1.12 \mathrm{~kg} / \mathrm{m}^{3}$ [10]. Meanwhile, brake torque $(T)$, brake power $\left(P_{b}\right)$, brake specific fuel consumption $(b s f c)$, and thermal efficiency $\left(\eta_{t h}\right)$ are calculated with Eq. (2) to Eq. (5) [15]

$T=\frac{P b}{2 \pi N}$ 
$P_{b}=V x I$

$$
b s f c=\frac{m_{f}}{P_{b}}
$$

$\eta_{t h}=\frac{P_{b}}{m_{f} x L H V_{f}}$

where $\mathrm{N}$ is the engine's shaft rotational speed (rpm), $\mathrm{V}$ and I are the voltage (Volt) and the electric current (Ampere), and $\mathrm{LHV}_{\mathrm{f}}$ is the lower heating value of the fuel $(17 \mathrm{MJ} / \mathrm{kg})$ [15]

\section{Results}

Figure 3 shows engine rotational speed at compression ratio of 7.5, 8.5 and 9.5. Engine speed decreases as electric load increases for all observed compression ratio. Theoretically, the engine rotational speed should not reduce since the generator is equipped with a mechanical governor. The governor adjusts the fuel flow rate according to the load applied on the engine. Governor regulates amount of fuel injected to the combustion chamber. More amount of fuel is injected at higher load, thus the engine speed is kept constant. However, the reduction of engine rotational speed is observed at increasing electric load during the investigation. This is due to a low pressure of biogas in the cylinder which means that the amount of biogas used is limited. The amount of biogas supplied to the combustion chamber is less than the requirement at increasing electrical load, even though the biomass flow rate is controlled by the governor.

Significant reduction in engine rotational speed occurs as increasing electric load at compression ratio of 7.5. The reduction is lower at compression ratio 8.5 and 9.5. The engine rotational speed relatively stable at compression ratio 8.5 for all electrical load observed. The pressure at the end of compression stroke steps up as increasing compression ratio and results in better combustion occurs during combustion process, and obviously generate more power to overcome the electric load of the generator. However, the engine rotational speed at compression ratio 9.5 is less stable than that at compression ratio 8.5. Compression ratio increases further up to 9.5, the pressure and temperature inside the cylinder also further increases which may cause knocking during combustion process. As we know that, the compression ratio of SI engine is limited by octane number of the fuel.

From Figure 3, it can be seen that very high engine rotational speed is observed at electric load of $60 \mathrm{~W}$. This may due to sudden opening of fuel valve from the biogas cylinder to the engine, which causes more amount of biogas flows to the combustion chamber, results more power developed. Meanwhile the electric load applied is only $60 \mathrm{~W}$, thus the engine rotational speed steps up abruptly from its rated speed, i.e. $3000 \mathrm{rpm}$. In order to get more comprehensive result of an effect of compression ratio on engine rotational speed, the engine has to be tested at its rated speed, such that at $3000 \mathrm{rpm}$. In accordance with generator frequency and power output $(P=V \mid \operatorname{Cos} \varnothing)$, the engine rotational speed should be at $3000 \mathrm{rpm} \pm 200 \mathrm{rpm}$. 


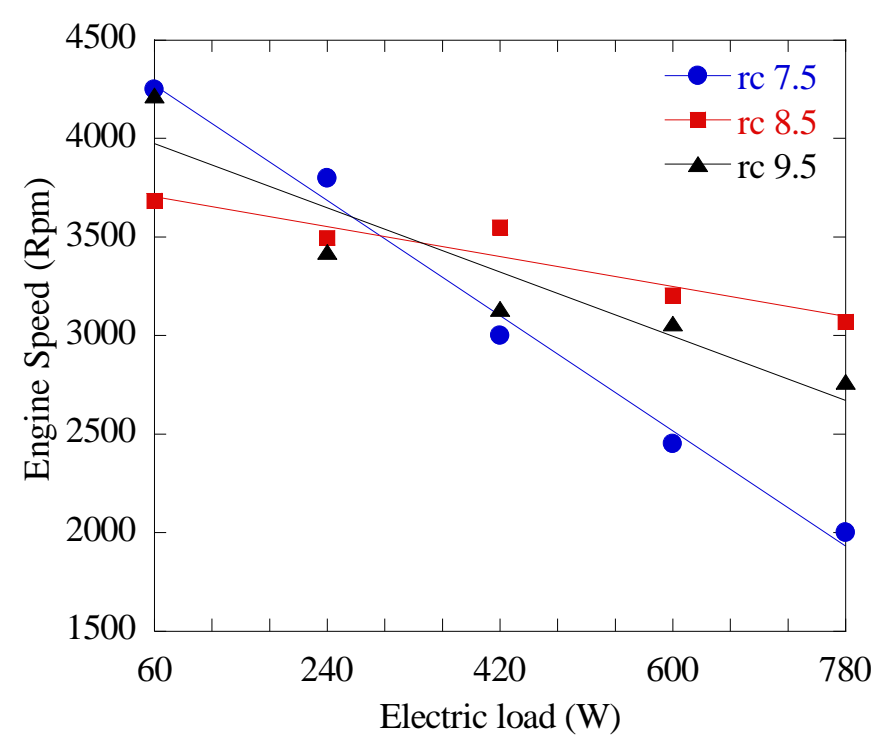

Fig. 3. Engine speed

Figure 4 and Figure 5 display brake power and torque of the engine. Similar trend between power and torque are observed. The brake power and torque of the engine incline as increasing compression ratio from 7.5 to 9.5 and decline from compression ratio 9.5 to 10.5 under all load conditions. Higher compression ratio results in higher cylinder pressure, thus higher work done on the piston during power cycle of the engine and, consequently generates higher brake power and torque. Maximum brake power and brake torque occur at compression ratio of 9.5. The maximum brake power of $450.37 \mathrm{~W}$ and brake torque of $1.66 \mathrm{Nm}$ are observed under load test of $600 \mathrm{~W}$. Further increasing compression ratio from 9.5 to 10.5 , the brake power and torque decline. It may due to abnormal combustion occurs at compression ratio of 10.5. The mixture of air and biogas burnt in absence of spark from spark plug, known as detonation. The combustion occurs is due to very high cylinder pressure. This inappropriate combustion leads to decrease output power and torque of the engine. Operated at high compression ratio, the octane number of the fuel have to be high enough to prevent the detonation. The octane number of the biogas was typically $130[15,17]$

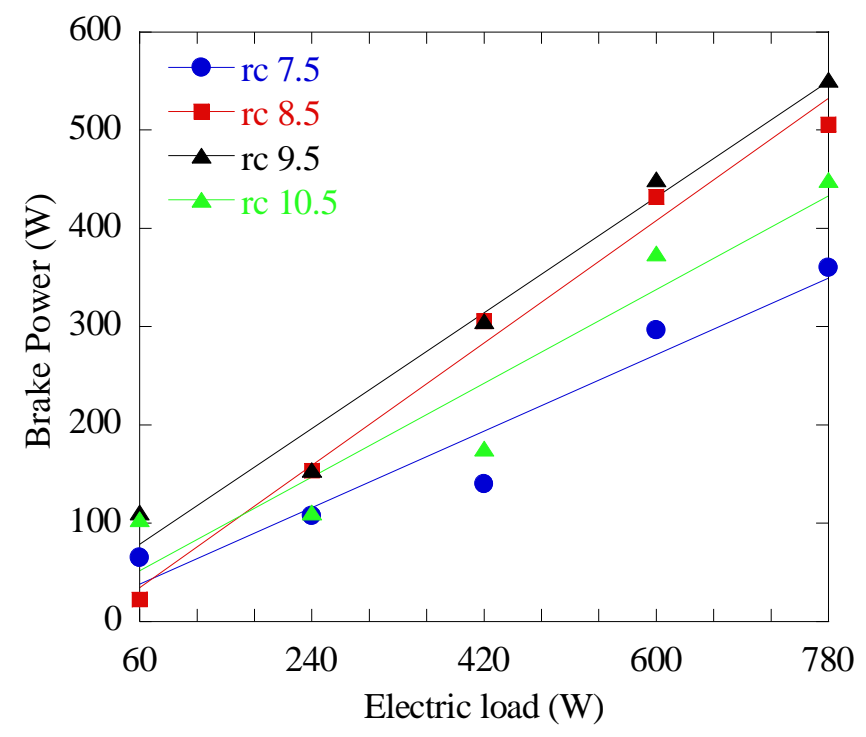

Fig. 4. Brake power 


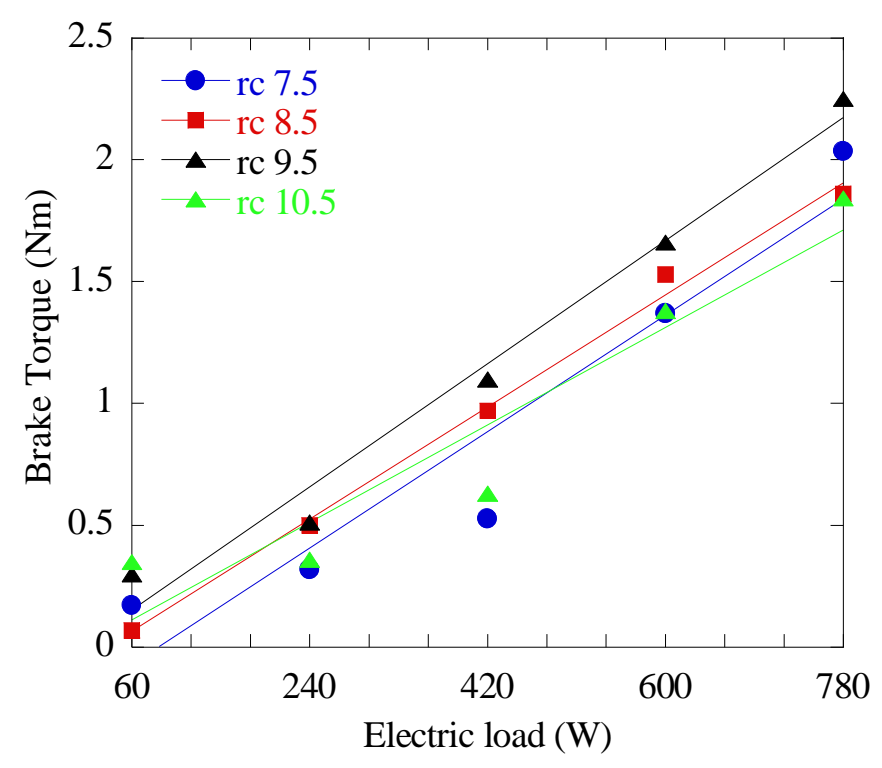

Fig. 5. Brake torque

Figure 6 presents an effect of compression ratio on brake specific fuel consumption (bsfc) of the generator set engine under load test of 240,420, and $600 \mathrm{~W}$. The bsfc declines as increasing compression ratio from 7.5 to 9.5, but it steps up when compression ratio moves to 10.5 . This trend is observed for all load conditions. Typically, the bsfc ranges from 0.5 to $8 \mathrm{~kg} / \mathrm{kW} . \mathrm{h}$ in the present work. The value is comparable with the work obtained by Haryanto et al., 2019 [27] whose obtained the bsfc of biogas fuel home scale genset was in the range of $2-17 \mathrm{~g} / \mathrm{W}$.h. The minimum bsfc at compression ratio of 9.5 is $0.59 \mathrm{~kg} / \mathrm{kWh}$ under load condition of $600 \mathrm{~W}$. The graph also indicates that the bsfc is lower at higher load condition. Lower the bsfc means that more efficient the engine.

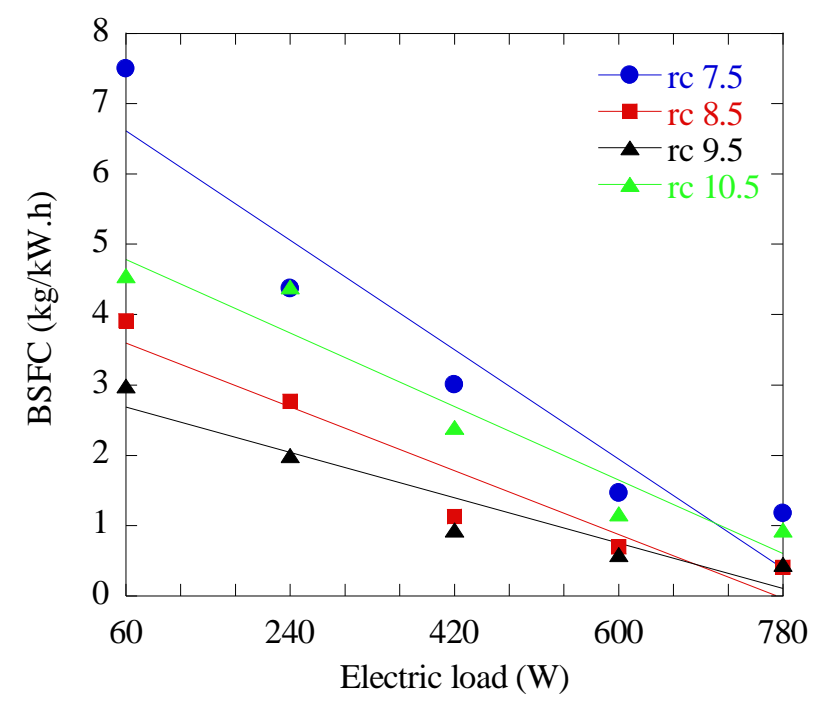

Fig. 6. Brake specific fuel consumption rate

Figure 7 displays an effect of compression ratio on brake thermal efficiency of the engine at load condition of 240, 420, and 600 Watt. Theoretically, thermal efficiency increases as increasing compression ratio. For all load conditions, the thermal efficiencies incline from compression ratio 7.5 to 9.5. However, thermal efficiency of the engine at compression ratio 10.5 is lower than the same at compression ratio 9.5. After touching maximum value at compression ratio of 9.5 , the thermal efficiencies fall at compression ratio of 10.5 in the present work. Since thermal efficiency is defined 
as a ratio between brake power and energy released by the fuel (Eq. (5)) in the current work, where the maximum thermal efficiency at compression ratio 9.5 is due to the highest brake power output of the engine occurs at compression ratio of 9.5 . The maximum thermal efficiency of about $27 \%$ is observed at load test of $780 \mathrm{~W}$.

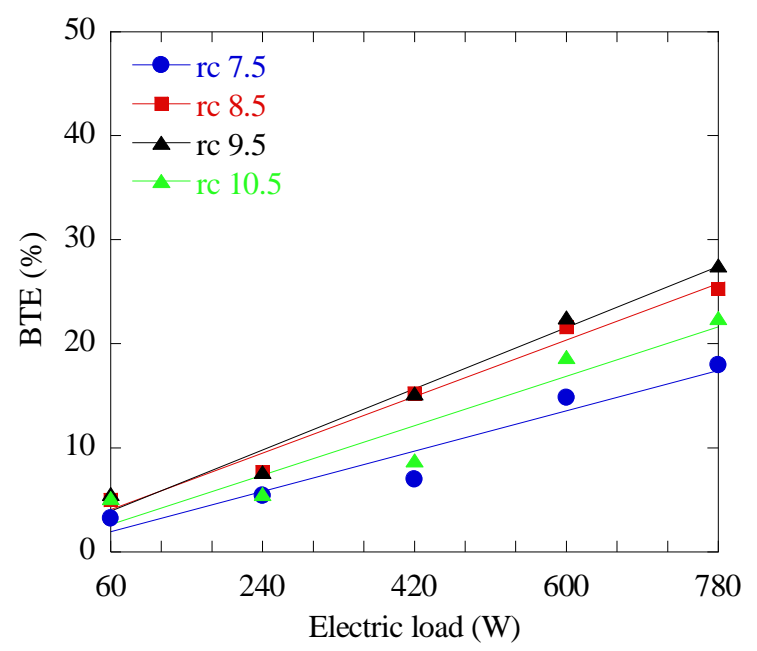

Fig. 7. Thermal efficiency

\section{Conclusions}

Brake power, brake torque, brake specific fuel consumption, and thermal efficiency of the $3 \mathrm{~kW}$ generator set fuelled with raw biogas are experimentally investigated at different compression ratios. The conclusions can be drawn from the work are

i. Compression ratio affects the brake power, brake torque, brake specific fuel consumption, and thermal efficiency of the engine

ii. For all load condition observed, similar trend of brake power, brake torque, brake specific fuel consumption, and thermal efficiency are observed.

iii. Optimum compression ratio for the engine fuel with raw biogas is 9.5. At the optimum compression ratio, maximum brake power, brake torque, and thermal efficiency of the engine are $450.37 \mathrm{~W}, 1.66 \mathrm{Nm}$, and $46.93 \%$, respectively. Meanwhile, minimum brake specific fuel consumption is $0.59 \mathrm{~kg} / \mathrm{kWh}$ at this optimum compression ratio.

iv. In the future work, it is suggested that to investigate an effect of air fuel ratio and biogas pressure on performance of the engine,

\section{Acknowledgement}

The authors would like to thanks Mrs. Nur Hayati, M.Eng, Head of Laboratory of Automotive-IST AKPRIND, for providing the laboratory facilities to conduct the experiment work.

\section{References}

[1] Widyaningsih, Grita Anindarini. "Peraturan Presiden Nomor 22 Tahun 2017 tentang Rencana Umum Energi Nasional." Jurnal Hukum Lingkungan Indonesia 4, no. 1 (2017): 139-152. https://doi.org/10.38011/ihli.v4i1.53

[2] Lubis, Hamzah. "Renewable Energy of Rice Husk for Reducing Fossil Energy in Indonesia." Journal of Advanced Research in Applied Sciences and Engineering Technology 11, no. 1 (2018): 17-22.

[3] Linn, Cheah Yi, Mohd Radzi Abu Mansor, and Zul Ilham. "Performance and Emission of Palm Oil Methyl Ester Biodiesel with Various Additives in Direct Injection Diesel Engine." Journal of Advanced Research in Materials Science 72, no. 1 (2020): 1-14. https://doi.org/10.37934/arms.72.1.114 
[4] Costa, Rodrigo C., and José R. Sodré. "Compression ratio effects on an ethanol/gasoline fuelled engine performance." Applied Thermal Engineering 31, no. $2-3 \quad$ (2011): https://doi.org/10.1016/j.applthermaleng.2010.09.007

[5] Doğan, Battal, Derviş Erol, Hayri Yaman, and Evren Kodanli. "The effect of ethanol-gasoline blends on performance and exhaust emissions of a spark ignition engine through exergy analysis." Applied Thermal Engineering 120 (2017): 433-443. https://doi.org/10.1016/i.applthermaleng.2017.04.012

[6] Thakur, Amit Kumar, Ajay Kumar Kaviti, Roopesh Mehra, and K. K. S. Mer. "Progress in performance analysis of ethanol-gasoline blends on SI engine." Renewable and Sustainable Energy Reviews 69 (2017): $324-340$. https://doi.org/10.1016/i.rser.2016.11.056

[7] Barakat, Y., Ezis N. Awad, and V. Ibrahim. "Fuel consumption of gasoline ethanol blends at different engine rotational speeds." Egyptian Journal of Petroleum 25, no. $3 \quad$ (2016): $309-315$. https://doi.org/10.1016/i.ejpe.2015.07.019

[8] Costagliola, Maria Antonietta, Maria Vittoria Prati, Salvatore Florio, Pietro Scorletti, Daniele Terna, Paolo lodice, Dario Buono, and Adolfo Senatore. "Performances and emissions of a 4-stroke motorcycle fuelled with ethanol/gasoline blends." Fuel 183 (2016): 470-477. https://doi.org/10.1016/i.fuel.2016.06.105

[9] Yao, Yung-Chen, Jiun-Horng Tsai, and I-Ting Wang. "Emissions of gaseous pollutant from motorcycle powered by ethanol-gasoline blend." Applied energy 102 (2013): 93-100. https://doi.org/10.1016/i.apenergy.2012.07.041

[10] Karagöz, Mustafa, Suat Sarıdemir, Emrah Deniz, and Burak Çiftçi. "The effect of the CO2 ratio in biogas on the vibration and performance of a spark ignited engine." Fuel 214 (2018): 634-639. https://doi.org/10.1016/j.fuel.2017.11.058

[11] Zulkurnai, Fatin Farhanah, Norhidayah Mat Taib, Wan Mohd Faizal Wan Mahmood, and Mohd Radzi Abu Mansor. "Combustion Characteristics of Diesel and Ethanol Fuel in Reactivity Controlled Compression Ignition Engine." Journal of Advanced Research in Numerical Heat Transfer 2, no. 1 (2020): 1-13. https://doi.org/10.37934/cfdl.13.2.111

[12] Taib, Norhidayah Mat, Mohd Radzi Abu Mansor, and Wan Mohd Faizal Wan Mahmood. "Simulation of Hydrogen Combustion in Neon-Oxygen Compression Ignition Engine." CFD Letters 12, no. 12 (2020): 1-16. https://doi.org/10.37934/cfdl.12.12.116

[13] de Faria, Mário M. Nunes, Juan P. Vargas Machuca Bueno, Sami MM Elmassalami Ayad, and Carlos R. Pereira Belchior. "Thermodynamic simulation model for predicting the performance of spark ignition engines using biogas as fuel." Energy Conversion and Management 149 (2017): $1096-1108$. https://doi.org/10.1016/j.enconman.2017.06.045

[14] Verma, Saket, L. M. Das, and S. C. Kaushik. "Effects of varying composition of biogas on performance and emission characteristics of compression ignition engine using exergy analysis." Energy conversion and management 138 (2017): 346-359. https://doi.org/10.1016/i.enconman.2017.01.066

[15] Reddy, K. S., S. Aravindhan, and Tapas K. Mallick. "Investigation of performance and emission characteristics of a biogas fuelled electric generator integrated with solar concentrated photovoltaic system." Renewable Energy 92 (2016): 233-243. https://doi.org/10.1016/i.renene.2016.02.008

[16] Jatana, Gurneesh Singh, M. Himabindu, Hari S. Thakur, and R. V. Ravikrishna. "Strategies for high efficiency and stability in biogas-fuelled small engines." Experimental thermal and fluid science 54 (2014): 189-195. https://doi.org/10.1016/i.expthermflusci.2013.12.008

[17] Qian, Yong, Shuzhou Sun, Dehao Ju, Xinxing Shan, and Xingcai Lu. "Review of the state-of-the-art of biogas combustion mechanisms and applications in internal combustion engines." Renewable and Sustainable Energy Reviews 69 (2017): 50-58. https://doi.org/10.1016/i.rser.2016.11.059

[18] Irimescu, Adrian, Gabriel Vasiu, and Gavrilă Trif Tordai. "Performance and emissions of a small scale generator powered by a spark ignition engine with adaptive fuel injection control." Applied energy 121 (2014): 196-206. https://doi.org/10.1016/i.apenergy.2014.01.078

[19] Sawyerr, Nathaniel, Cristina Trois, Tilahun Workneh, and Vincent Ifeanyi Okudoh. "An overview of biogas production: fundamentals, applications and future research." International Journal of Energy Economics and Policy (2019).

[20] Schnurer, Anna, and Asa Jarvis. "Microbiological handbook for biogas plants." Swedish Waste Management U 2009 (2010): 1-74.

[21] Mogami, C. A., C. F. Souza, V. T. Paim, I. F. Tinoco, and R. S. Gates. "Methane concentration in biogas produced from dejections of milk goats fed with different diets." In 2006 ASAE Annual Meeting, p. 1. American Society of Agricultural and Biological Engineers, 2006.

[22] Sendzikiene, Egle, Alfredas Rimkus, Mindaugas Melaika, Violeta Makareviciene, and Saugirdas Pukalskas. "Impact of biomethane gas on energy and emission characteristics of a spark ignition engine fuelled with a stoichiometric mixture at various ignition advance angles." Fuel 162 (2015): 194-201. https://doi.org/10.1016/i.fuel.2015.09.019 
[23] Topgül, Tolga, Hüseyin Serdar Yücesu, Can Cinar, and Atilla Koca. "The effects of ethanol-unleaded gasoline blends and ignition timing on engine performance and exhaust emissions." Renewable energy 31, no. 15 (2006): 25342542. https://doi.org/10.1016/j.renene.2006.01.004

[24] Yücesu, Hüseyin Serdar, Tolga Topgül, Can Cinar, and Melih Okur. "Effect of ethanol-gasoline blends on engine performance and exhaust emissions in different compression ratios." Applied thermal engineering 26, no. 17-18 (2006): 2272-2278. https://doi.org/10.1016/i.applthermaleng.2006.03.006

[25] Porpatham, E., A. Ramesh, and B. Nagalingam. "Effect of compression ratio on the performance and combustion of a biogas fuelled spark ignition engine." Fuel 95 (2012): 247-256. https://doi.org/10.1016/i.fuel.2011.10.059

[26] Cengel, Yunus A., Michael A. Boles, and Mehmet Kanoglu. Thermodynamics: an engineering approach. Vol. 5. New York: McGraw-hill, 2011.

[27] Haryanto, Agus, Tj GT Nindhia, Winda Rahmawati, Udin Hasanudin, T. W. Saputra, A. B. Santosa, and S. Triyono. "Effect of load on the performance of a family scale biogas-fuelled electricity generator." In IOP Conference Series: Earth and Environmental Science, vol. 355, no. 1, p. 012078. IOP Publishing, 2019. https://doi.org/10.1088/1755$1315 / 355 / 1 / 012078$ 